Poznań

\title{
Political sciences: a discipline of the social sciences or the humanities?
}

\begin{abstract}
By virtue of an administrative decision, the division of Polish academia into fields and disciplines was verified in 2011. It is owing to this process that political science, among others, was reassigned in Poland. Before September 30, 2011, political science was classified as one of the humanities, but later on it was included in the new field of the social sciences, created as a result of the division of the humanities. This decision started an ongoing discussion, also in the circles of political scientists, on the issue of how advisable this change is, and it has become an important task to confirm the thesis that this decision was substantially justified. It is assumed that political science as a discipline has more in common with other disciplines assigned to the social sciences than the humanities. Additionally, by way of developing a new register of academic fields and disciplines, the administrative divisions in Polish academia were to a large extent aligned with the classification of fields and disciplines adopted by the OECD, UNESCO and EUROSTAT, which will facilitate the internationalization of academic collaboration. The above organizations and institutions, and - consequently - some of their member states, have already divided the humanities, which used to be alternatively named social sciences, into two separate fields: the social sciences and the humanities. In order to justify the above-mentioned thesis it was necessary to determine how academic specialization, discipline and field of science are perceived today; to indicate the essential divisions in academia; to attempt to define the specific nature of the humanities versus social sciences; and to present the relations of political science to the latter category. The assessment of how intensive these relations are, made it possible to confirm that the above-mentioned thesis is justified.
\end{abstract}

Key words: political science, social sciences, humanities, classification of sciences

In the $19^{\text {th }}$ century, academic research intensified on account of the accelerated abandonment of feudal limitations, a realization of what economic and civilizational merits can result from the work of scholars and research teams, and state patronage over research centers accompanied by the increase in their number and the number of their staff. This brought about an accelerated growth in the number of academic specializations and disciplines. Since this process is ongoing, it has become necessary to supplement the present classifications and taxonomies of academic disciplines, as well as come up with new ones, on a regular basis. It has also become feasible to distinguish new disciplines and fields of learning, divide the existing ones and assign the existing disciplines to different fields of academia. It is owing to such a process that political science has been reassigned in Poland. Before September 30, 2011, political science was classified as one of the humanities, but later on it was included in the new field of social sciences, created as a result of the division of the humanities (Rozporzadzenie...; Uchwała...; Konstytucja...). Therefore, I adopt the thesis that this decision was substantially justified, since, given the current legal status quo, political science as a discipline has more in common with other disciplines assigned to the social sciences than the humanities. Additionally, 
by way of developing a new register of fields and disciplines, the administrative divisions in Polish academia were to a large extent aligned with the classification adopted by the OECD, UNESCO and EUROSTAT, which will facilitate the internationalization of academic collaboration. The above organizations and institutions, and - consequently - some of their member states, have already divided the humanities, which used to be alternatively named social sciences, into two separate fields: the social sciences and the humanities. In order to justify the above-mentioned thesis it will be necessary to determine how academic specialization, discipline and field of science are perceived today; to indicate the essential determinants of divisions in academia and basic criteria for such divisions; to attempt to define the specific nature of the humanities versus social sciences; and to determine the factors confirming the tight relation of political science to the latter category.

In order to properly asses the divisions in academia it is necessary to determine the units that facilitate such divisions. There exists a relative consensus in this area. The smallest unit of division is an academic (research) specialization. Andrzej Chodubski reckons that a specialization is distinguished by "a strictly defined scope of research, appropriate sources and research methods as well as the means of action" (Chodubski, 2013, p. 21). This definition finds an apt complementation in a statement by Stanisław Kamiński, who sees a specialization as a "permanently shaped set of issues within a given academic discipline" (Kamiński, 1981, p. 231). One might add that, given the present scope of knowledge and current division of tasks pertaining to academic activities, every scholar and research team typically tends to operate within the limits of their respective academic specialization. The description of such a scholar or research team is usually founded on the identification of such a specialization. If scholars consider themselves to be experts in many different specializations, justified concerns arise as to their competence. The "set of issues" that distinguishes a given specialization can sometimes be the subject of interest of two or more academic disciplines.

According to Stanisław Kamiński, a discipline is "a part of learning that is coherent in terms of logic and content that, on the given level of its development and in certain conditions, can be efficiently mastered with reference to creative research and teaching by a single scholar" (Kamiński, 1981, p. 231). Chodubski approaches disciplines as "the branches of academia distinguished on the basis of the following criteria: the object of studies, a strictly defined scope, appropriate sources and research methods as well as means of action (Chodubski, 2013, p. 21). To some extent, this definition is elaborated by Benon Miśkiewicz, who notes that the matter of interest of a given discipline "encompasses a defined part of the natural or social world designated to be examined" (Miśkiewicz, 1976, p. 48). The theses presented by the above authors are complemented in an interesting manner by Tadeusz Kotarbiński, who names a discipline "a subject that constitutes any whole that deserves to be intellectually taught in higher education institutions and only at this level, as a separate specialization" (Kotarbiński, 1970, p. 41).

Although one can still come across opinions denying political science the status of a discipline, albeit less and less often (Skarzyński, 2012), the above-presented arguments make it possible to state that political science meets all the criteria, allowing its status as a rightful academic discipline to be acknowledged. Firstly, it has a relatively defined object and scope consisting in the studies of whatever is political in social life (Skarzyński, 
2012, pp. 279-286). Secondly, political scientists have access to sources they can collect, select, analyze and, on that basis, develop assessments and draw conclusions, taking, in the course of such activities, advantage of academic methods and techniques appropriate for research into the social sciences and some disciplines of the humanities. Thirdly, political science has an increasing range of means of action. These encompass faculties, institutes, departments and sections in different higher educational institutions, as well as the Institute of Political Studies of the Polish Academy of Sciences (PAN), alongside all their staff, libraries, editorial boards of magazines and facilities these organizational units have at their disposal. Fourthly, political science is a course taught at the level of higher education. Faculties of political science are present in practically every university, where they are quite successful, as confirmed, among other things, by the evaluations of the Polish Accreditation Committee (PKA). Yet the advances made in political science make it increasingly difficult to fulfill the conditions required for a discipline to be distinguished, as defined by Kamiński. Therefore, the specializations of political science as we know them have provided the foundation to distinguish further majors of studies (such as international relations, state governance, social policy and public policies). There have also emerged attempts by some research teams, rather than officials, to transform specializations in political science into separate disciplines where academic degrees could be conferred. ${ }^{1}$ Examining the development of different sciences, it can be seen that such endeavors have numerous precedents, but in the light of the achievements of political science within the framework of its different specializations so far (e.g. international political relations) they should be deemed highly premature.

A field of learning is understood as a set of disciplines interested in similar parts of the natural or social world, each approaching the studies of this part from its own point of view, thereby contributing to gathering a more comprehensive knowledge of this part. Disciplines operating in the same field frequently share similar research methods and techniques. There are, however, fields of learning where there are no disciplines. This usually results from the fact that the development of academic specializations pursued within their scope is insufficient to ensure them the status of a discipline. In the light of current regulations, no disciplines have been distinguished in the field of theology, veterinary science, pharmacology and pharmacy, health sciences and sport and fitness sciences. Distinguishing academic disciplines is also significant in the process of teaching faculty members, among other things. After all, academic degrees are conferred in a given field with respect to one of the disciplines it encompasses, provided that such a discipline has been distinguished. An academic title, in turn, refers to the title of professor in a given field.

Moving on to the typology ${ }^{2}$ of the fields and disciplines of academia, their considerable variety should be noted (Kamiński, 1981, pp. 244-250). ${ }^{3}$ The criterion for division is always selected with respect to its objectives. Although the classification of academic fields and disciplines is not the purpose of this paper, in order to ensure the clarity of

${ }^{1}$ Such expectations are particularly noticeable in the activities of some researchers of international relations.

${ }^{2}$ For more on this topic see: Wallas, 2015, pp. 257-262.

${ }^{3}$ Many typologies of both historic value and relatively current are presented by S. Kamiński. For more see: Kamiński, 1992, pp. 244-250. 
further considerations, and - even more importantly - to attempt to position political science in academia in general, it is worth referring to Kamiński's classification proposal, presented in Graph 1. For Kamiński, the first criterion to divide academia is the source of knowledge leading to academic cognition. Such source can come from the truths revealed and accepted by faith, or information acquired by way of observation, experimentation and analysis of the reality that surrounds researchers. Taking into account the scope of academic research, subjects can be divided into philosophy that "seeks the ultimate rationale of the world approached in ontic categories" and special sciences that "seek permanent regularities in the formal, qualitative or quantitative aspect of the object of research." Special sciences are further divided into formal sciences, capable of verifying hypotheses or justifying theses without resorting to experimentation. Empirical sciences in turn "are based primarily on experimentation and [...] inductive reasoning." They are generally divided into natural sciences and the humanities (social sciences). The former examine "animate and inanimate nature and - to be more precise - they study the physical properties of the geographic environment and animate creatures, including humans." The latter study "the social human" and artifacts of his culture "seeking their typical characteristics that make it possible to interpret human behavior and the nature of their artifacts" (Kamiński, 1981, pp. 249-250; Miśkiewicz, 1970, pp. 49-50).

\section{Graph 1. Taxonomy of sciences according to Stanisław Kamiński}

Division criterion:

Academia

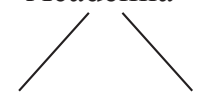

Source of knowledge: Theology Natural knowledge

Scope of research: Philosophy

Scope of research: $\quad$ Philosophy

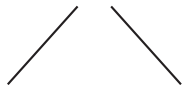

Explanation mode:

Formal sciences (deductive) (inductive)

Object of study:

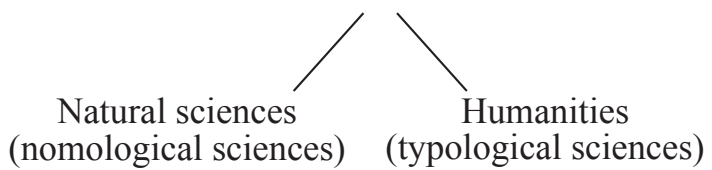

Source: Own elaboration based on: S. Kamiński, Pojęcie nauki i klasyfikacja nauk, Lublin 1981, pp. 249-250. By the same author, Nauka i metoda. Pojęcie nauki i klasyfikacja nauk, Lublin 1992, p. 274.

Naturally, the above taxonomy is one of many possible ones, yet the author of this one "in a simple and unifying manner" managed to take into account the criteria of other divisions of academia. In spite of the many years that have passed since it was devised and presented for the first time in 1961, its general framework remains valid. Interestingly, Kamiński noticed the multifariousness of both the natural sciences and the humanities and made attempts to systematize them. On account of the purpose of the considerations here, it is important that he identified at least three groups of dis- 
ciplines within the humanities as they were understood in those times, namely: "man and society," "cultural artifacts," and "the history of the social human." The first group encompassed "psychology, ethnology, (cultural) anthropology [and] socio-economic sciences." The second group featured "law, religious studies, morality studies, arts studies and language studies" whereas the third one - history (Kamiński, 1981, p. 267). It can be assumed that political science, which was still at the initial stage of its development in Poland when the taxonomy in question was published, ${ }^{4}$ would have been included in the group of socio-economic sciences had Kamiński listed the disciplines there.

A similar differentiation in the humanities was also noticed by Miśkiewicz, who, however, tended to name them social sciences, and less frequently, but interchangeably, used the name of the humanities (Miśkiewicz, 1970, p. 50). A similar standpoint was taken by J. Such, who included political science among the essential social sciences (humanities) (Such, 1987, p. 303). Given the present level of development in academia, it is becoming increasingly risky to alternately apply the names of humanities and social sciences to the same group of disciplines, and this rightly triggers discussion and opposition.

The most comprehensive and frequently updated classifications nowadays are developed for the purpose of academic administration. It is by means of administrative decisions that research units are established, state grants for such research and education of scholars are made, the rights to confer academic degrees are granted, academic degrees and titles are conferred, second-cycle (MA) and third-cycle (doctoral) studies are established in basic organizational units of higher educational institutions provided that they conduct academic research in a given academic field and discipline.

Yet any attempt at a new division of academia into fields and disciplines, or its modification stirs controversy and triggers discussions, especially among those directly affected, or even protest. ${ }^{5}$ This was the case following the publication of the above-mentioned regulation, when the Committee of Political Science of the Polish Academy of Sciences (PAN), enjoying the support in the form of resolutions of the boards of many units of higher educational institutions conducting research in the field of political science and providing education in the major of political science, acknowledged that it was unjustified to formally distinguish a new discipline of "public policy studies." The Committee further expressed its dissatisfaction with the division of the field of the humanities as they were prior to September 30, 2011 into two separate fields of social sciences and the humanities; the Committee pointed to the similarities of the object and methodology of the disciplines encompassed by the two currently divided fields of academia.

On the basis of the Resolution of the Central Committee for Degrees and Titles of October 24, 2005 on the fields of science and arts as well as scientific and artistic disciplines, which was in force until September 30, 2011, the following disciplines were classified as humanities: archeology, bibliology, ethnology, philosophy, history, art history, language studies, cultural studies, literature studies, security studies, defense studies, political science, cognition and social communication studies, arts studies, management

${ }^{4}$ The traditions of research and studies in political science in Poland are presented, among others, in: Krauz-Mozer, Borowiec, Ścigaj, 2011. See also: Pasierb, 2005, pp. 104-119.

${ }_{5}$ The reason for that is the progressing differentiation of subjects and the resulting lack of precise classification criteria. This topic is discussed, among others, by: Chodubski, 2013, p. 20; Kamiński, 1992, pp. 227-234. 
studies, educational sciences, psychology, religious studies and sociology (Uchwata...). At present, on the basis of the Regulation that has already been mentioned several times, the humanities continue to encompass archeology, bibliology, information studies, ethnology, philosophy, history, art history, language studies, cultural studies, literature studies, arts studies, management studies, religious studies, and a new discipline was added: family studies. The field of social sciences encompasses security studies, defense studies, political science, cognition and social communication studies, educational sciences, psychology and sociology. New disciplines were also added to this field, such as media studies and public policy studies (Woźnicki, 2012, pp. 133-151).

In order to answer the essential question of what field of academia should accommodate political science, an attempt should be made, first and foremost, to explain the nature of the humanities and that of the social sciences. Referring to the findings of other authors (especially Polish ones) is only partly useful, as the majority of considerations on the humanities date back to the period preceding its formal division into separate fields.

Since empirical sciences that cannot fall within the category of natural sciences (see Graph 1) undoubtedly share their general object of research and, to a considerable extent, also methodology (Such, 1987, p. 300), ${ }^{6}$ the differences between them cannot be very sharp. Therefore the words "more" and "rather" should be particularly frequent when describing their specific character and distinguishing between the social sciences and humanities. This is so because these two fields are only differentiated by the level of intensity of the same feature. Taking this into consideration, I assume that the social sciences are studies of society distinguished, among other things, by the following properties:

1) their methodology is closer to natural sciences. Trying to systematize the humanities in the way presented in Graph 1, Kamiński was driven by their relations to natural sciences and rightfully assumed that the "disciplines studying man and society" were closest to the humanities (Kamiński, 1992, p. 267) because the social sciences to a greater extent make it possible to verify hypotheses by experimentation and simulations;

2) they allow basic research, applied research and even experimental development to be conducted (Organizacja Współpracy Gospodarczej i Rozwoju, 2010, pp. 89-91). ${ }^{7}$ After all, "[i]n general, but more particularly in the field of the social sciences, the purpose of a study is to prepare the way for decisions by policy makers at the level of government (central, regional, local) or in industrial and trading enterprises (Organizacja Współpracy Gospodarczej i Rozwoju, 2010, p. 46);

${ }^{6}$ It should be noted that J. Such is right, observing that "the object of research to a large extent determines all the remaining criteria. The nature and properties of the object determine the selection of research methods and procedures compliant with the general issues of science, its tasks and objectives." For more see: Such, 1987, p. 300.

7 The OECD defines the nature of such research stipulating that " $[\mathrm{b}]$ asic research is experimental or theoretical work undertaken primarily to acquire new knowledge of the underlying foundations of phenomena and observable facts, without any particular application or use in view." By contrast, "[a]pplied research is also original investigation undertaken in order to acquire new knowledge. It is, however, directed primarily towards a specific practical aim or objective." Finally, "[e]xperimental development is systematic work, drawing on knowledge gained from research and practical experience, that is directed to producing new materials, products and devices; to installing new processes, systems and services; or to improving substantially those already produced or installed.” For more see: Organizacja Współpracy Gospodarczej i Rozwoju, 2010, pp. 89-91. 
3) they are more concerned with researching social groups and the collaboration of their members in order to attain a goal, which integrates the given group, and with seeking regularities related to such collaboration;

4) they are focused on seeking regularities in the relations of collaborative or competitive social groups;

5) they stress studying the present and forecasting the development of social life. The specific nature of the humanities, in turn, involves the following, among other things:

1) smaller methodological bond with natural sciences. In Kamiński's opinion, historic sciences are the furthest from such sciences and, compared to the social sciences, "they provide material for most controversial opinions" (Kamiński, 1992, p. 267). In studies on the object of interest of the humanities, experimentation plays a significantly smaller role in the verification of hypotheses;

2) feasibility of basic research and, eventually, applied research to be conducted in the humanities. Experimental development is unlikely.

3) researching individuals rather than groups, their spiritual development and determinants of their social activities;

4) focusing on studying primarily the products of human mind (such as language, arts, ideas);

5) attaching greater importance to establishing facts, explaining the genesis of the present and seeking the sources of current phenomena in the past.

Taking the above into consideration, it should be acknowledged that political science fulfills the criteria of the social sciences more than those pertaining to the humanities. This is so because:

a) political science makes it possible for hypotheses to be verified by means of experimentation and simulation, although their results should be treated with utmost caution. Political scientists, similarly to the representatives of other social sciences, and in contrast to researchers into natural sciences, face considerably greater difficulties when formulating objective conclusions. This is caused, among other things, by the fact that participants of their studies can pursue some unspoken interests and values and fail to tell the truth or behave in conformity with the expectations of the majority in order to maintain the appreciation within their group. Therefore, the adopted hypotheses should be verified by means of possibly numerous research methods and techniques (Johnson, 2010, pp. 56-61; Kuszyk-Bytniewska, 2015, pp. 191-197); ${ }^{8}$

b) it is possible to conduct basic research, applied research and even experimental development in political science. While political scientists deal with basic research most often, it is possible for them to conduct also such research where the results are related directly to practice. The results of experimental development, taking into account the results of basic and applied research, can be commissioned, for instance, by a public administration body in the form of a program or model of conduct to be applied in practice after its key assumptions have been verified on a social group selected by random choice or otherwise. Assuming, for example, that the object of research is the policy of integration of foreigners, the objective of the basic research

${ }^{8}$ For more about threats faced by political science see for instance: Johnson, Reynolds, Mycoff, 2010, pp. 59-61; Kuszyk-Bytniewska, 2015, pp. 191-197. 
into this issue will involve the examination of the policy of integration of foreigners in selected countries and its evolution. The task of applied research, in turn, will be to examine the policy of integration of foreigners in Poland and identify the determinants for its optimum efficiency. The objective of experimental development can be the development of a program for the integration of foreigners in Poland and testing it on a selected group of foreigners in a given local community, school, company or refugee center;

c) the research object in political science is politics as a social activity, among other things. The objectives of such an activity are determined by individual or group interests and can be implemented only in the relations with other individuals or groups. The condition necessary to make such relations effective involves winning trust or support, encouraging a large social group to become active, or dissuading another group from being active;

d) political science studies whatever is political in social life, including politics. As a consequence, its scope of interest covers, according to Stephen D. Tansey, "a wide range of situations in which people driven by different interests work together to realize the objectives that consolidate them, and compete with each other when the goals are contradictory" (Tansey, 1997, pp. 18-19);

e) the object of interest of political science covers contemporary political life and the processes initiated in the past provided that they are still continued. However, political scientists refer to the results of historical research as they make it possible to present and explain the origins of institutions and events of the political realm of social life and to forecast its development. The contemporary political history dealing with the closed events of the past, however, is a part of history instead of political science.

An academic field should encompass related disciplines; therefore the accuracy of classifying political science as a social science can be verified by means of determining the relations binding political science with other disciplines of the social sciences and the humanities, respectively. When analyzing these relations direct connections between political science and all the disciplines in the field of social sciences can be noted in the partly shared object of research and the possibility of applying similar research tools. The same holds true also for some disciplines classified as the remaining fields of the social sciences, that is economics and management studies in the field of economics, as well as law and administration studies in the field of law.

The relations with other disciplines within the humanities are diversified, though. Political scientists find philosophy and history the most useful as the sources of the knowledge of politics. This is so because these two disciplines have already expanded their interest in politics to an extent allowing them to develop the sub-disciplines of the philosophy of politics (within philosophy) and political history (in history). The findings of other humanities are less relevant for political science for two reasons. One is the definitely smaller interest in the studies of political determinants in the development of arts, culture and language. The other one is that political science continues to expand the scope of its interest and develops in terms of, for instance, staff, becoming gradually able to tackle new research topics following this development. This process has resulted in the currently increased interest of political scientists in the role of language, music and 
other arts in political activities, which finds confirmation in the form of research results published in papers and books.

Although the sub-disciplines of different sciences have similar names (for instance, the studies of internal security policy have the status of a sub-discipline in political science while a sub-discipline named in the same way is a part of security studies; economic policy studies are a sub-discipline in economics, while the same name is also given to an important element of political science) they are not shared sub-disciplines of respective sciences. The only shared thing is their research object. Economic policy is studied by economics, political science and public policy studies, but each of them does so from its point of view and is driven by the goals it is expected to fulfill. The fact that two or even three different disciplines have chosen the same fragment of political life as their research object does not have to mean that they compete with one another. On the contrary, such studies provide different paths leading to the expansion of academic knowledge about politics and politicality (Heywood, 2006, p. 19).

It should be noted that the outcomes of studies conducted within political science have, or at least should have, considerable importance. Political science provides among other things the knowledge about the nature of everything that is political, about the determinants of political life and the mechanisms and instruments of political struggle. Taking advantage of the achievements of political science by other disciplines allows them to increase the effectiveness of their own studies, lower their cost and primarily increase the accuracy of theses and forecasts made.

The statement that political science constitutes a significant element of social sciences is confirmed by some international classifications. One such classification is that developed under the patronage of the General Secretariat of the OECD and partly presented in Table 1. Its most recent version was published in 2006. It is an outcome of negotiations between the experts from the OECD, UNESCO and Eurostat (European Statistical Office, an organizational unit of the EU European Commission, located in Luxembourg). This classification was drawn up in order to run comparative statistical studies of academic activity in EU member states and their academic policy. The need to develop this taxonomy was also determined by the escalated international collaboration of local research centers and scholars and by the activities of supranational research institutions and teams that are established increasingly often. An internationally acknowledged classification is also demanded by organizations and institutions granting funds for academic activities. The European Union plays a highly important role in this respect having allocated considerable resources to the Horizon 2020 research and innovation program. Given the authority of the above-mentioned organizations, the classification they proposed has been recognized in many countries outside the OECD (Organizacja Współpracy Gospodarczej i Rozwoju, 2010, p. 3).

On the basis of the analysis of the experience of different countries running academic activities it can be said that the classification presented in Table 1 is the outcome of a compromise achieved taking into consideration their traditions, the present expectations of scholars and institutions set up to administer science (Maciejko, 2015). Its advantage is its openness to development which is likely to result in the addition of further disciplines. It is possible to expand each academic field by adding another division unit in the item "other sciences." What is important from the point of view under considera- 
tion here, is the fact that the classification concerned divides disciplines into six fields, including the social sciences and humanities, unambiguously including political science in the former category.

Undoubtedly, one of the objectives of the official modification to the division of Polish academia made by the Minister of Science and Higher Education in 2011 was to align this division with internationally recognized standards. Therefore, the humanities were divided into the fields of social sciences and the humanities. In order to retain the large number of fields that had been distinguished before, and which can be assumed to have become a tradition for Polish scholars, another division unit of the area of study (Polish: obszar wiedzy) was introduced. Owing to the classification of academic fields into the areas of study, the current Polish classification is highly similar to that established by the OECD. Without getting into the details, it can be noted that the higher number of the areas of study (eight) than the six fields of science (FOS) defined by the OECD results from the division of natural sciences into the "area of exact sciences" and the "area of natural sciences" while the humanities are divided into the "area of the humanities" and the "area of arts." Taking these differences into account it can be concluded that the areas of study grouping the current fields of academia in Poland are equivalent to the fields of science according to the OECD classification.

Table 1

Fields of science and technology classification according to the OECD

\begin{tabular}{|c|c|}
\hline Fields of science & Disciplines* \\
\hline 1 & 2 \\
\hline 1. Natural sciences & \\
\hline 2. Engineering and technology & \\
\hline 3. Medical and Health sciences & \\
\hline 4. Agricultural sciences & \\
\hline 5. Social sciences & $\begin{array}{l}\text { 5.1. Psychology } \\
\text { - Psychology (including human-machine relations); } \\
\text { - Psychology, special (including therapy for learning, speech, hearing, } \\
\text { visual and other physical and mental disabilities); } \\
\text { 5.2. Economics and Business } \\
\text { - Economics, Econometrics; } \\
\text { - Industrial relations; } \\
\text { - Business and Management; } \\
\text { 5.3. Educational sciences } \\
\text { - Education, general; including training, pedagogy, didactics; } \\
\text { - Education, special (to gifted persons, those with learning disabilities); } \\
\text { 5.4. Sociology } \\
\text { - Sociology; } \\
\text { - Demography; } \\
\text { - Anthropology, ethnology, } \\
\text { - Social topics (Women's and gender studies; Social issues; Family stud- } \\
\text { ies, Social work); } \\
\text { 5.5. Law } \\
\text { - Law, criminology, penology; } \\
\text { 5.6. Political science } \\
\text { - Political science; } \\
\text { - Public administration; } \\
\text { - Organisation theory; }\end{array}$ \\
\hline
\end{tabular}




\begin{tabular}{|c|c|}
\hline 1 & 2 \\
\hline & $\begin{array}{l}\text { 5.7. Social and economic geography } \\
\text { - Environmental sciences (social aspects); } \\
\text { - Cultural and economic geography; } \\
\text { - Urban studies (Planning and development); } \\
\text { - Transport planning and social aspects of transport (transport engineer- } \\
\text { ing to be 2.1); } \\
\text { 5.8. Media and communications } \\
\text { - Journalism; } \\
\text { - Information science (social aspects); } \\
\text { - Library science; } \\
\text { - Media and socio-cultural communication; } \\
\text { 5.9. Other social sciences } \\
\text { - Social sciences, interdisciplinary; } \\
\text { - Other social sciences; }\end{array}$ \\
\hline 6. Humanities & $\begin{array}{l}\text { 6.1. History and Archaeology } \\
\text { - History (history of science and technology to be 6.3, history of specific } \\
\text { sciences to be under the respective headings); } \\
\text { - Archaeology; } \\
\text { 6.2. Languages and Literature } \\
\text { - General language studies; } \\
\text { - Specific languages; } \\
\text { - General literature studies; } \\
\text { - Literary theory; } \\
\text { - Specific literatures; } \\
\text { - Linguistics; } \\
\text { 6.3. Philosophy, Ethics and Religion } \\
\text { - Philosophy, History and philosophy of science and technology; } \\
\text { - Ethics (except ethics related to specific subfields); } \\
\text { - Theology; } \\
\text { - Religious studies; } \\
\text { 6.4. Arts (arts, history of arts, performing arts, music) } \\
\text { - Arts, Art history; } \\
\text { - Architectural design; } \\
\text { - Performing arts studies (Musicology, Theater science, Dramaturgy); } \\
\text { - Folklore studies; } \\
\text { - Studies on Film, Radio and Television; } \\
\text { 6.5. Other humanities }\end{array}$ \\
\hline
\end{tabular}

* The division of fields into disciplines and sub-disciplines is presented only for the social sciences and the humanities. For more see: Organizacja Współpracy Gospodarczej w Rozwoju, 2010, pp. 303-310.

Source: Organizacja Współpracy Gospodarczej i Rozwoju, Podręcznik Frascati. Proponowane procedury standardowe dla badań statystycznych $w$ zakresie działalności badawczo-rozwojowej (Organisation for Economic Co-operation and Development. Frascati Manual. Proposed Standard Practice for Surveys on Research and Experimental Development), Ministry of Science and Higher Education, 2010, pp. 303-310, http://www.nauka.gov.p1/g2/oryginal/2013_05/08935db1c9f7adf15c087d07720a984f.pdf. July 9, 2016.

In conclusion it should be noted that the above-presented arguments justifying the classifications presented confirm the fact that political science as a discipline is a part of the field of social sciences. These classifications will, however, continue to be modified or even changed on account of the increasing interdisciplinary nature of academic research. It turns out that this interdisciplinarity has the "immense merit of creating unlimited possibilities to generate new knowledge. Contemporary knowledge, character- 
ized by its incessant changes of relations between the fields (areas) of study and the permanent mutual influence of different specializations, finds it difficult to develop within the framework of traditional disciplines created within the confines of specializations and academicism" (Kuc, p. 24). The criteria of divisions in academia will increasingly involve research topics that will attract scholars from different subjects. Internet browsers have already started to play an important role in this process, using key words rather than the names of disciplines to access knowledge on a given topic developed within different disciplines. It should therefore be assumed that the best outcomes of academic cognition will be generated on the grounds of "interdisciplines, mutlidisciplines and transdisciplines" (Kuc, p. 24). ${ }^{9}$ This was confirmed by the findings of the Gulbenkian Commission on the Restructuring of the Social Sciences, established in 1993 and headed by Immanuel Wallerstein. It stated that in order for the social sciences to further develop it is necessary to 'restructure' them. The activities that will facilitate such restructuring involve: "the development of integrated research programs within university structures going across the traditional divisions" into disciplines; employing professors at more than one faculty and offering interdisciplinary doctoral studies. The Commission opted also for the tighter collaboration of the "traditional social sciences: economics, political science and sociology" (Wyzwania..., 1999, pp. 54, 104-106).

\section{Bibliography}

Chodubski A. J. (2013), Wstęp do badań politologicznych, Wydawnictwo Uniwersytetu Gdańskiego, Gdańsk.

Heywood A. (2006), Politologia, Wydawnictwo Naukowe PWN, Warszawa.

Johnson J. B., Reynolds H. T., Mycoff J. D. (2010), Metody badawcze w naukach politycznych, Wydawnictwo Naukowe PWN, Warszawa.

Kamiński S. (1992), Nauka i metoda. Pojęcie nauki i klasyfikacja nauk, Towarzystwo Naukowe Katolickiego Uniwersytetu Lubelskiego, Lublin.

Kamiński S. (1981), Pojęcie nauki i klasyfikacja nauk, Towarzystwo Naukowe Katolickiego Uniwersytetu Lubelskiego, 3rd edition, supplemented, Lublin.

Kotarbiński T. (1970), Studia z zakresu filozofii, etyki i nauk społecznych, Zakład Narodowy imienia Ossolińskich - Wydawnictwo, Wrocław-Warszawa-Kraków.

Krauz-Mozer B., Borowiec P., Ścigaj P. (2011), Kim jesteś politologu? Historia i stan dyscypliny w Polsce, vol. I, Wydawnictwo Uniwersytetu Jagiellońskiego, Kraków.

Kuc B. R., O nauce, dyscyplinach naukowych i kierunkach ich rozwoju, http://docplayer.pl/3854353-Onauce-dyscyplinach-naukowych-i-kierunkach-ich-rozwoju.html, July 9, 2015.

Kuszyk-Bytniewska M. (2015), Problematyzacja obiektywności w naukach społecznych, "Zagadnienia Naukoznawstwa", no. 3.

D. Maciejko, Klasyfikacja dziedzin i dyscyplin naukowych w badaniach statystycznych, http://www. nauka.gov.pl/polska-nauka/klasyfikacja-dziedzin-i-dyscyplin-naukowych-w-badaniach-statyst ycznych,archiwum,1,akcja,pdf.html, August 8, 2015.

Marcos A. (2012), Filozofia nauki. Nowe wymiary, Wydawnictwo Naukowe Uniwersytetu Mikołaja Kopernika, Toruń.

${ }^{9}$ Interesting conclusions on the future of social sciences are presented, for instance in the Report of the Gulbenkian Commission on the Restructuring of the Social Sciences "Open the Social Sciences." For more see: Wyzwania, 1999. 
Miśkiewicz B. (1976), Wstęp do badań historycznych, Poznań.

Organizacja Współpracy Gospodarczej i Rozwoju (2010), Podręcznik Frascati. Proponowane procedury standardowe dla badań statystycznych w zakresie działalności badawczo-rozwojowej, Ministerstwo Nauki i Szkolnictwa Wyższego, http://www.nauka.gov.pl/g2/oryginal/2013_05/089 35db1c9f7adf15c087d07720a984f.pdf, July 9, 2016.

Pasierb B. (2005), Z tradycji polskiej nauki o polityce (część 1). Nauka o polityce, kultura polityczna przełomu XIX i XX wieku, "Polityka i Społeczeństwo", no. 2.

Rozporządzenie Ministra Nauki i Szkolnictwa Wyższego z dnia 8 sierpnia 2011 r. w sprawie obszarów wiedzy, dziedzin nauki i sztuki oraz dyscyplin naukowych i artystycznych, Dz. U. [Journal of Laws] 2011, no. 179, item 1065.

Skarzyński R. (2012), Podstawowy dylemat politologii: dyscyplina nauki czy potoczna wiedza o spoteczeństwie?, Białystok.

Sobczyńska D. (1991), Między naukq a twórczościq artystycznq, in: Wspótczesna filozofia nauk, ed. T. Buksiński, Wydawnictwo Naukowe UAM, Poznań.

Such J. (1987), Klasyfikacja nauk, in: Filozofia a nauka. Zarys encyklopedyczny, eds. Z. Cackowski, J. Kmita, K. Szaniawski, P. J. Smoczyński, Zakład Narodowy imienia Ossolińskich - Wydawnictwo, Wrocław-Warszawa-Kraków-Gdańsk-Lódź.

Tansey S. D. (1997), Nauki polityczne, Wydawnictwo ZYSK i S-KA, Poznań.

Uchwała Centralnej Komisji do Spraw Stopni i Tytułów z dnia 24 października 2005 r. w sprawie określenia dziedzin nauki i dziedzin sztuki oraz dyscyplin naukowych i artystycznych, M. P. 2005, no. 79 , item 1120 .

Ustawa z dnia 14 marca 2003 r. o stopniach naukowych i tytule naukowym oraz o stopniach i tytule w zakresie sztuki, Dz. U. [Journal of Laws] 2003, no. 65, item 595 and Dz. U. 2011, no. 84, item 455.

Wallas T. (2015), Przyczynek do rozważań nad przynależnościq dziedzinowq nauk o polityce, "Politeja", no. 36 .

Woźnicki J. (2012), Nowa dyscyplina - ,nauki o polityce publicznej” usytuowana $w$ dziedzinie nauk społecznych, "Nauka", no. 1.

Wyzwania wobec nauk społecznych u progu XXI wieku (1999), prepared for print by A. Flis, translated by B. Lassaer, Kraków.

\section{Nauki o polityce: dyscypliną nauk społecznych czy humanistycznych?}

\section{Streszczenie}

W roku 2011, na mocy decyzji administracyjnej, dokonano korekty podziału polskiej nauki na dziedziny i dyscypliny naukowe. W rezultacie takiego procesu zmieniła się przynależność dziedzinowa m.in. nauk o polityce. Do 30 września 2011 r. dyscyplina ta zaliczana była do dziedziny nauk humanistycznych, a po tej dacie włączono ją do nowej dziedziny nauk społecznych, która została wyodrębniona w wyniku podziału tej pierwszej. Ponieważ zmiana ta wywołała trwającą do dziś dyskusję na temat celowości dokonanej reformy także wśród politologów, ważnym zadaniem podjętych badań była próba potwierdzenia tezy, wg której decyzja taka była uzasadniona merytorycznie. Założono bowiem, że dyscyplina nauki o polityce, w porównaniu z dyscyplinami nauk humanistycznych, ma więcej cech wspólnych z innymi dyscyplinami zaliczonymi do dziedziny nauk społecznych. Ponadto, poprzez ustalenie nowego wykazu dziedzin i dyscyplin naukowych, administracyjne podziały w polskiej nauce zostały w znacznym stopniu dostosowane do klasyfikacji dziedzin i dyscyplin wypracowanych na forum OECD, UNESCO i EUROSTAT, co ułatwi internacjonalizację współpracy naukowej. Na forach tych organizacji i instytucji, a co za tym idzie także w wielu ich państwach członkowskich, już 
wcześniej podzielono nauki humanistyczne - kiedyś zamiennie nazywane naukami społecznymi - na dwie dziedziny: nauk społecznych i nauk humanistycznych. W celu potwierdzenia słuszności ww. tezy w toku rozważań konieczne było: ustalenie współczesnego pojmowania istoty specjalności naukowej, dyscypliny naukowej i dziedziny nauki; wskazanie najważniejszych podziałów w nauce; podjęcie próby określenia specyfiki dziedziny nauk humanistycznych oraz dziedziny nauk społecznych, a także ukazanie relacji nauk o polityce z tymi dziedzinami nauk. Ocena intensywności takich relacji umożliwiła potwierdzenie słuszności przyjętej tezy.

Słowa kluczowe: nauki o polityce, nauki społeczne, nauki humanistyczne, klasyfikacja nauk 